\title{
Türkiye'de Eğitim Alanında Çalışan STK'ların 4+4+4 Eğitim Sistemi Bağlamında Hazırladıkları Raporlarda Din Eğitimine Yaklaşımlarının Değerlendirilmesi
}

\author{
M. Fatih Güvendi*
}

\section{Giriş}

Eğitim; insanların ve toplumların şekillenmesinde ve değişmesinde en önemli araçlardan biridir. 21. yüzyııın hızla değişen dünyasında eğitim, bilginin üretilmesi, kullanılması ve aktarılmasının dinamiklerini oluşturarak, sosyal hayatta ağırlığını daha etkin olarak hissettirmeye başlamıştır. Sosyal, siyasal ve kültürel değişimin dinamiklerinden biri olan eğitim, Türkiye'de de önemini giderek arttırmakta ve farklı düzenlemeleri beraberinde getirmektedir. Eğitim sisteminde uygulanan değişiklikler, yapılan yatırımlar, geliştirilen ve uygulanan projeler bu değişimin en büyük göstergesi olmuştur (Erdoğan, 2014). Türkiye'de son yıllarda eğitimde uygulanan en önemli projelerden birisi, 2012-2013 eğitim-öğretim yılında yürürlüğe giren ve $4+4+4$ olarak bilinen 12 yıllık zorunlu eğitim sistemidir.

4+4+4 eğitim sisteminin iki temel amacından biri, toplumun ortalama eğitim süresini arttırmak, diğeri ise, eğitim sistemini bireylerin ilgi, ihtiyaç ve yeteneklerine göre düzenlemektir (Milli Eğitim Bakanlığı [MEB], 2012). Bu eğitim sistemi ile kronik sorunların giderilmesinde, veli, öğrenci, öğretmen ve müfredat bağlamında bir uyumun ve geçişliliğin sağlanması amaçlanmaktadır. Bu yeni eğitim sistemi hiç kuşkusuz, İslami kesimin yanı sıra diğer inanç gruplarının da uzun yıllardan beri beklediği bir dönüşümü ve rahatlamayı da beraberinde getirmiştir. 28 Şubat süreci ile yaşanan 8 yıllık kesintisiz eğitimle sekte vurulan pek çok dinî kurum ve kuruluşun önünün açılması yolunda da ciddi adımlar atılmıştır (Eğitimciler Birliği Sendikası [Eğitim-Bir-Sen], 2013). Ancak, toplumun dindar' kesimlerinde hâlâ bir tedirginlik söz konusudur. Alevi inançları konusunda raporlar hazırlayan Norveç-Helsinki Komitesi (NHC) (2014), dindar kesimin, devletin din eğitimi ile ilgili sunduğu imkânları, müfredatları, etkinlikleri, faaliyetleri yetersiz bulduğunu, çocuklarına hâlâ bağımsız bir din eğitimi aldıramadıkları hususunda sorun yaşadıklarını belirtmektedir. Diğer taraftan devlet eliyle verilmeyen din eğitiminin, başka problem ve sıkıntıları beraberinde getireceği de ayrı bir tartışma konusudur.

* Yüksek Lisans Öğrencisi, Marmara Üniversitesi, Eğitim Bilimleri Enstitüsü, Eğitim Programları ve Öğretim Anabilim Dalı.

1 Çalışmanın farklı yerlerinde, İslami kesim, Alevi kesim, dindar kesim, dini hassasiyeti olan kesim gibi farklı kavramlar geçmektedir. Bu çalışmada kastedilen, din eğitimi ile ilgili belirli talepleri olan, kendi inanç, görüş ve din anlayışını yaşayan, yaşatmaya çalışan, inançlarını yaşamak konusunda hassasiyet taşıyan kesimler kastedilmektedir. 
Din eğitimi ile ilgili hazırlanan bu çalışma, Türkiye'deki sivil toplum kuruluşlarının din eğitimi ile neyi anladıkları, beklentileri, ihtiyaçları, değerlendirmeleri ve önerileri dikkate alınarak hazırlanmıştır. Araştırmada, din eğitimi ve öğretimi kavramları detaylıca incelenmiş, raporlarda bu kavramların karşılaştırmalı olarak incelenmesi sağlanarak farklılıklara vurgu yapılmıştır. Ayrıca bu araştırmada; din eğitimi müfredatı, din dersleri öğretim programlarının yapısı (kazanım, etkinlikler, ölçme değerlendirme vb.), STK'ların isteğe bağlı ve seçmeli din derslerinden beklentileri, isteğe bağlı din eğitimi tartışmaları, din eğitimine ilişkin öğrenci, öğretmen ve veli tutumları ile yeni eğitim sistemine ilişkin öneriler raporlar eşliğinde tartışılmış ve değerlendirilmiştir. Bu makalenin en önemli amacı, araştırma raporlarında karşılaşılan sorunların tespit edilmesi, raporlarda ihtiyaç hissedilen bölümlerin giderilmesi hususunda bundan sonra hazırlanacak olan raporlara bir ön fikir vermektir. Bu araştırmada konu edilen ilgili araştırma raporları şunlardır:

1. Türkiye'de Din Öğretimi Forumu Sonuç Raporu, TiMAV, 2012.

2. 4+4+4 Eğitim Sistemi, Yeni Anayasa'da Dinî Kurumlar, Din Eğitimi ve Öğretimi, Isteğe Bağıı Din Eğitimi, Ensar Vakfı, 2012.

3. Seçmeli Din Eğitimi Dersleri, İnceleme ve Değerlendirme Raporu, DEM, 2013.

4. 4+4+4 Eğitim Reformunu İzleme Raporu, Eğitim-Bir-Sen, 2013.

5. Yeni Eğitim Sisteminde Seçmeli Din Dersleri, İmkânlar, Fırsatlar, Aktörler, Sorunlar ve Çözüm Önerileri, İLKE Derneği, 2013.

\section{Bir Kavram Karmaşası Olarak Din Eğitimi, Bilimsel Din Eğitimi ve Din Öğretimi}

Türkiye'de din eğitimi ve öğretimi, çeşitli ideolojik zeminlerde ele alınıp değerlendirildiği için farklı tanımlamalara rastlamak mümkündür. Diğer taraftan, MEB'in müfredatlarında din eğitimi ile amaçlar ve kazandırıması gereken beceriler ele alınırken, din eğitimi ve din öğretimi kavramlarının tanımlarına rastlanılamaması problem doğurmaktadır. Bu tanımlama eksikliğine araştırma raporlarında da değinilmemesi çalışmaların din eğitimi ve din öğretiminin içeriği hakkında bilgiye ulaşmakta zorluk yaşanmasına sebep olmaktadır. Bundan dolayı bu kavramları bilimsel bir dille tanımlayıp açıklamak önemlidir. Bu nedenle yazı içerisinde öncelikli olarak din eğitimi ve din öğretimi kavramına, araştırılan raporların ilgili kısımlarından atıflar yapılarak ve ilgili literatür taranarak bütünlüklü bir bakış açısı oluşturulmaya çalışılmıştır. Ancak raporlarda din eğitimi ve din öğretimi kavramlarına yeteri kadar yer verilmediği görülmüştür. Raporların din eğitimi ve öğretimini kavramsal düzlemde ele alması başlıca hedefleri arasında olmasa bile, raporlarda bu tanımların üzerine inşa edilen tespitler vardır ve bu tespitlerin değerlendirilmesinde belli bir bakış açısı mevcut olmalıdır. Bu bağlamda bu kavramları yeniden ele alarak nesnel bir tanımlamaya ulaşmak gerekmektedir. Tanımların yeri geldikçe birbirlerinin yerlerine kullanılması ve anayasada net ifadelerin bulunmaması vb. durumlardan kaynaklı yapılan tanımların, problemli kalmaya devam edeceği başka bir eleştiri konusu olarak karşımıza çıkmaktadır.

Din eğitimi ve din öğretimi kavramları değerlendirildiğinde, din eğitimi kavramının din öğretimini kapsadığı görülür. Dini toplumda yaşanılır kılma, dini öğretme, eylem ve söylemlerde bulunma din eğitimi kavramı içerisinde yer alırken, din öğretimi dinin yasal olarak 
okullarda öğretilmesini esas almaktadır. Bu bağlamda din eğitimi kavramını kullanmak bizim çalışmalarımız için de daha kapsayıcı olacaktır. Bir diğer ifadeyle, din eğitiminin eğer toplumda bir anlamı olmayacaksa, yaşama-uygulama alanı bulamazsa burada eğitimden bahsetmek mümkün olmaz. Okullarda verilen ve bilişsel düzeyde kalan din eğitimi de bu konuda yeterli olmaz. Din yalnızca epistemolojik bir alan değil, ontolojik olarak hayatta anlam arayışıdır. Bu açıdan din eğitimi ve öğretimi sadece bilişsel boyutta değil duygu boyutunda da önemsenmesi gerekir (Kaymakcan, 2005). Armaner (1958), din öğretiminin inançlı insanlarla verilebileceğini ve zihnin menşurundan geçirilerek, ruha sindirilmesi, ruha mal edilmesi gerektiğini belirtmiştir. Bu sadece din dersi için geçerli olmayıp, sosyal bilimler ve fen bilimleri için de geçerlidir. Bu çalışmada da, din eğitimi kavramını kullanarak, gerek öğretim boyutu, gerek toplumda yaşanılır kılma hususu, gerekse de düşünce ve eylem birlikteliğinin oluşması hedeflenmiştir.

Bilimsel din eğitimi kavramı ise, bilim eğitimi ile din eğitimini uzlaştırma çabası olarak önümüze çıkmaktadır. Bilimsel din eğitim yaklaşımı, dinlerin temel prensiplerini ve metafizik unsurlarını geri plana atan, daha çok seküler bir ahlak eğitimini savunmaktadır. Bu yaklaşımda, bilim ile çelişen noktalar öğretimde geri planda kalmakta, öğrencilerin din ya da dinler hakkında bilgilenmesi hedeflenmektedir (Çekin, 2013a, 137). Ülkemizdeki din öğretimi yaklaşımı, bilimi önemseyen, öğretim programlarının geliştirilmesinde dinî muhtevayı bilimsel bir çerçevede ele alan, ahlak eğitimine din eğimi ve öğretimi içerisinde yer veren, İslam'ın bilimi desteklediğini savunan bir anlayışa sahiptir. Bu durumda bilimsel din eğitimi yaklaşımının, ülkemizdeki uygulamalarla benzerlikler gösterdiği durumlar olmakla beraber farklı açılardan büyük oranda ayrışmakta olduğu da görülmektedir (Çekin, 2013a, 136).

\section{Din Eğitimi, Dinler Hakkında Eğitim, Din Kültürü, Seçmeli Din Dersleri, İsteğe Bağlı Din Eğitimi Tartışmaları}

Din eğitimi ile ilgili tartışmaları iki ana soru başlığı altında toplamak mümkündür. Bu iki soru şöyle ifade edilebilir: Din eğitimi, dinî faaliyet şeklinde mi ele alınmalı, yoksa kültürel boyutuyla (başka bir tanımlama ile dinler hakkında eğitim) mı ele alınıp değerlendirilmelidir. Bu konu ya da soru, çalışmaların en önemli sorularından birini oluşturmaktadır. Bu düşüncelerde din eğitimi, dinî inanç ve faaliyet şeklinde ele alınırsa, dinî inancı geliştirmek için yapılan her türlü planlı ve plansız organizasyonu, düşünceyi, eylemi, söylemi vb. ele alarak değerlendirme yapmak gerekir. Bu görüş, bir taraftan, devletin din eğitimi ve öğretimi ile ilgili elini güçlendirecek, inanç özgürlüğünü arttıracak, dinî hassasiyeti olan kesimleri rahatlatacak, evde-işyerinde-ibadethanelerde, dinî kurum-kuruluşlar ile cemaatlerde ve toplumda da din eğitiminin ve inancın yaygınlaşmasını da beraberinde getirecektir. Diğer taraftan bu görüş, eleştirel bakış ve kişisel özgürlük gibi liberal değerlere yeterince önem vermediği, bilgi açısından vahyi tartışmasız bilgi kaynağı olarak gördüğü, bu tür eğitimde dinî otoriteyi rasyonel bazda değerlendirme olanağının olmayışı ve çocukları çok dinli ve kültürlü hayata hazırlayamadığı gibi konularda eleştirilecektir (Çekin, 2013b, 138). Diğer taraftan laiklik ilkesine hassasiyeti olan kesimlerde ise bu tür bir eğitim tanımı tedirginlik oluşturacaktır. Din, salt kültürel boyutuyla (dinler hakkında eğitim) ele alınırsa, farklı dinlerin ya da dinî olmayan dünya görüşlerinin öğretilmesinde tarafsız bir pozisyon benimsenir. Bu yaklaşımda farklı dinlerin ve inançların öğretilmesi; öğrencileri alternatiflerden haberdar etme ve yaşamlarında farklı dinleri seçme konusunda seçenek sunmaktadır. Bu görüş, 
günümüz toplumlarının ve devletlerinin benimsediği görüştür. Günümüz liberal eğitim hedef ve yöntemleriyle bu yaklaşım tamamen uyum içerisindedir (Çekin, 2013b, 139). Bu eğitim tanımında, dinî hassasiyeti olan kesimler için, dinin içselleştirilememesi, toplumda yaşanır kılınmaması, dine ve dinî kültür, inanç, değer, ilgi, tutum ve davranışlara yansımaması şeklinde eleştiriye tabi tutulacaktır. Bu iki görüşle din eğitimi ve dinler hakkında eğitim sorunu devamlı gündeme gelip tartışma konusu olacak, inançlarını özgürce yaşamak isteyen dindar kesimler ile dinin kültürel boyutta kalması gerektiğini savunan kesimler arasında huzursuzluk devam edecektir. Diğer taraftan Halstead (2005), yaptığı değerlendirmelerde bu iki görüşü birleştirip öğretmenlerin bu iki yaklaşımı bir arada uygulayarak, öğrencilerinde hem dinî inancın gelişmesi sağlayabileceğini hem de eleştirel duruşun oluşmasını mümkün kılabileceğini belirtmektedir.

Batı'da liberal anlayışın geçerliliği ve din ile bilimin görüş olarak ayrıştığı toplumlar için geçerli olan bu tespit, Türkiye gibi dinî hassasiyeti olan toplumlar için yeterli ve geçerli bir görüş değildir. Bu iki farklı görüş temelde birbirinden belirgin sınırlarla ayrılmıştır. Bu iki görüşü toplumda uzlaşır kılmak zor görünmektedir. Halstead'ın (2005) belirttiği gibi öğretmenleri bu iki yaklaşımın arasında bırakmak, başka problemleri beraberinde getirir. Diğer taraftan öğretmenler, ister liberal bir din anlayışını savunsun isterse dini toplum içinde yaşanır kılma düşüncesinde olsun dinî inancın gelişmesini sağlayabilirler.

Çelikkaya'ya (1996) göre, dinî kurallarla yönetilen ülkelerde din, toplumu şekillendiren bir rol oynadığı için, din eğitimi, temel eğitim niteliği taşır. Laik ülkelerde ise din, kültürün bir parçası olduğundan din eğitimi de ikinci derecede bir eğitim statüsüne dönüşmektedir.

İki görüşün birbiriyle orta yolu bulması zor görünse bile din eğitimi ve dinler hakkında eğitim kavramları bilimsel bir düzlemde ele alınırsa ve nesnel bir biçimde tanımlanırsa farklıııkların ve ortak noktaların belirlenmesiyle bir uzlaşı oluşturulabilir. Aslında gerek İslam dini üzerinde hassasiyeti olan kesimler ile gerekse diğer inanç kesimlerinin beklentileri birbirinden çok farklı değildir. Özellikle inanç konusunda hassasiyeti olan kesimler çocuklarını daha dindar bir nesil olarak yetiştirme çabası içindedirler. Diğer taraftan dine karşı mesafeli olan kesimler ise ahlaki ve kültürel boyutlarda bir öğretiminin olması gerektiğini düşünmektedirler. Bunlardan hariç, dinî eğitime ve öğretime tamamen karşı olan kesimler açısından da zorunlu bir din eğitiminden vazgeçilerek ortak kültürel ve ahlaki değerler daha çoğulcu olarak ders kitaplarında yer alarak bu farklılıklar giderilebilir.

2011 yılında Eğitim Reformu Girişimi (ERG) tarafından yayınlanan "Türkiye'de Din ve Eğitim: Son Dönemdeki Gelişmeler ve Değişim Süreci” başlıklı raporda bu durumun altı çizilerek, şu ifadelere yer verilmektedir:

Dinler hakkında eğitim ve dersin zorunlu statüsü tartışmaları dışında, Türkiye'de önemli bir çoğunluğun örgün eğitimde din eğitimi yapılmasını talep ettiği özellikle kamu tarafından sıklıkla dile getiriliyor. Ancak isteğe bağlı din eğitiminin DKAB dersinin eleştirel, nesnel ve çoğulcu olması gereken içeriği ve felsefesiyle çelişmeyecek bir biçimde yapılandırılması için nasıl bir yol izlenmesi gerektiği konusunda görüş birliği olduğu söylenemez. Benzer bir biçimde isteğe bağlı din eğitiminin örgün eğitim içinde mi yoksa dışında mı sunulacağı, içeriği kimlerin belirleyeceği, eğitimin kimler tarafından verileceği ve finansmanının nasıl olacağı konusunda tartışmalar sürüyor. Farklı seçeneklerin ülkemizdeki inanç çeşitliliğini yansıtan katılımcı bir süreç içerisinde uzmanlar tarafından tartışııması ve kabul edilebilir, uygulanabilir ve sürdürülebilir bir öneri geliştirilmesi gerekiyor. 
Seçmeli ya da isteğe bağlı din derslerini toplumların istekleri ve talepleri doğrultusunda ve toplumsal uzlaşı ile değerlendirmekte yarar vardır. Ancak bu talepler kavramların belirginleşmesi, açık ve net tanımlarla ifadelendirilmesi, gerçekçi-bilimsel bir bakış açısıyla ele alınması, nesnel bir düzlemde değerlendirilmesi ve okullarda öğretmenler tarafından işler kılınmasıyla gerçekleştirilebilecektir. Diğer taraftan bu yönler inmal edilirse, kavramsal temellerin toplumda işler kılınması zor görünmektedir.

\section{Dünya'da ve Türkiye'de Din Eğitimi ve Öğretimi}

Ülkelerin tarihsel yaşanmışlıkları, politik ve felsefi görüşleri, toplumsal yapıları, psikolojik durumları, teknoloji okur-yazarlığı temel alınarak eğitim politikaları belirlenir. Toplumun değerleri, inançları ve normları, sadece onları öğreterek değil aynı zamanda eğitim sisteminin işleyişine dâhil edilerek korunur ve gelecek nesillere aktarılır. Bu noktada okullar, gençlere uygun davranış ve değerleri aşılayarak ve "nesil kopukluğunu birleştirerek" "gencin sistematik bilgiyi kazanmasına yardımcı olmasında" yaşamsal bir kurum olma vasfını yerine getirirler (Ornstein ve Hunkins, 2014). Ülkeler; tarihlerinden koparlarsa, insani değerlerden uzak kalırlarsa, toplumun dinamiklerini, beklentilerini karşılamaktan imtina ederlerse, eğitim politikalarının başarılı olması beklenemez. Bu durum eğitimde toplumsal dinamiklerinin belirleyici bir unsuru olarak karşııık bulmaktadır. Bir ülkenin toplumsal aklı, tarihsel gerçeklerle ve yaşanmışlıklarla, dinî inanç, gelenek ve görenekleriyle, günün ihtiyaçlarının paralelinde, teknolojik ilerlemenin uzlaşısıyla şekillenir ve güncelliğini korur. Ancak bu kodlar belirgin sınırlarla birbirinden ayrılırlarsa ve toplumla zıtlaşılırsa eğitimde özellikle din eğitiminde başarılı olunması mümkün değildir.

Karşılaştırmalı eğitim üzerinde çalışan eğitimciler, eğitimin problemlerinin ve amaçlarının birçok ülkede benzer olmasına karşın, çözüm yollarının tarihî gelişime, gelenek ve kültüre ait farklııkların etkisi altında olduğunu savunmuşlardır. Bu görüşü dile getiren Ayhan'a (2004) göre eğitim sistemini belirleyen faktörler şu başlıklar altında toplanmıştır:

1. Milli birlik duygusu

2. Dinî ve kültürel miras dâhil olmak üzere temel inançlar ve gelenekler

3. Genel ekonomik durum

4. İleri eğitim düşüncesi, bilimsel ve teknolojik gelişmeler

5. Dil problemleri (Anadil ve yabancı dil öğretimi)

6. Siyasi yapı

\section{Uluslararası işbirliği anlayışı bakımından takınılan tavır}

Dünya'da ve Türkiye'de din eğitiminin gelişim seyri birbirinden farklııı arz etmiştir. Bu farklılığın temel sebebi, laiklik ilkesinin değişik şekillerde anlaşılmasından kaynaklanmıştır. Din eğitiminin devlet eliyle mi yoksa dinî kurumlar eliyle mi verilmesi tartışması günümüze kadar geçerliliğini korumuştur. Bu durum, laiklik ilkesi paralelinde süregelen bir ayrışmayı da perçinlemiştir.

Batı ülkelerinde eğitimin kimin tarafından kontrol edeceği, okul ve müfredatlarının nasıl hazırlanacağı, öğretmenlerin nasıl yetiştirilip görevlendirileceği, ders kitaplarının yazıl- 
masında kilise ve devlet arasında tartışmalar olmasına rağmen, bu tartışmalar bir ülkede, birden çok dine inanan varsa, daha çok kendini göstermiştir. Eğer bir ülkede tek bir din hâkimse ve organize bir muhalefet yoksa o ülkede din eğitiminin okullara girmesi bakımından ciddi bir mesele olmamıştır (Ayhan, 2004).

Avrupa eğitim tarihine bakıldığında din ve kültür derslerinin okutulması konusunda bir tartışma yaşanmamıştır. Bu derslerin bireyin manevi ve vicdani gelişimi için vazgeçilmezliği öngörülmüştür. Tartışmalar genelde bu eğitimin doğrudan kilise tarafından mı yoksa devlet okullarında kilise tarafından kontrol edilen bir programla ve din adamlarının eliyle mi verilmesi gerektiği noktalarında yoğunlaşmıştır (Ayhan, 2004).

Fuess (2007), Orta Avrupa ülkelerindeki din eğitimi modelinde, din eğitimiyle ilgili sorumluluğun kamu kuruluşlarıyla kilise gibi dinî kuruluşlar arasında paylaşıldığını belirtir. Dinî öğretim programları çoğu zaman bu kurumun temsilcilerince beraber hazırlanır ve öğretmenleri de dinî kuruluşlar karşılar. Almanya'da uygulanan bu modelde, okulda din eğitimi saatinde öğrenciler dinlerine ve mezheplerine göre sınıflara ayrılır ya da ailelerinin isteğiyle bu derslerden muaf da tutulabilirler. Ayrıca öğrenci 15 yaşına geldiğinde kendi isteği ile de din eğitiminden ayrılabilir.

Türkiye'de, din eğitimi ve öğretimi, 1924 yılında çıkartılan Tevhid-i Tedrisat Kanunu ile ele alınmaya başlanmış ve tartışmaları da beraberinde getirmiştir. Görüşlerden birisine göre, dinin, tarihî ve millî bir kıymet taşıdığından bahsedilerek, çocuklara öğretilmesi gerektiği vurgulanmıştır (Okutan, 1980). Bu görüşe göre, bütün kötülüklerin, ahlaksızlıkların sebebi, iyi bir din ve ahlak eğitiminin alınmamasından kaynaklanmaktadır. Türkiye'nin laik bir ülke olduğuna vurgu yapılan diğer bir görüşe göre, laik bir ülkede zorunlu din dersi yer alamaz (Koçer, 1967). Bu görüşe göre, zorunlu din dersinin okutulması Atatürk ilkeleri ve inkılapları ile çağdaşlaşmanın önünde büyük bir tehlikedir (Aydın, 2007). Görüldüğü üzere Türkiye'de din derslerinin okutulması yönündeki tartışmalar, laiklik ekseninde odaklanmıştır. Bu tartışmalarda din dersleri kimi zaman tamamen müfredattan kaldııılmış, kimi zaman seçmeli ders olarak okutulmuş, kimi zaman ise zorunlu hâle getirilmiştir. Günümüzde de bu derslerle ilgili tartışmalar güncelliğini koruyarak devam etmektedir.

Bu hususta vurgulanması gereken son nokta, Türkiye'de örgün eğitim kurumlarında din eğitimi; 'zorunlu din öğretimi' adı altında gerçekleştirilmesine karşın; AB ülkelerinin çoğunda bu eğitim 'zorunlu din eğitimi' programı kapsamında yer almaktadır. Diğer bir ifadeyle Türkiye'de din öğretimi yapılırken, Avrupa ülkelerinde din eğitimi verilmektedir. Bu nedenle, Avrupa'da din dersi müfredatı oluşturulurken kiliselerin görüşlerine de yer verilmekte ve okullarda dinî ayinler ile dinî faaliyetlerin yapılabilmesine olanak sağlanmaktadır (Kap, 2014).

\section{Raporlarda Kavram Karmaşası}

Araştırma raporları incelendiğinde, literatürde belirtilen kavram karmaşalarının yaşandığı, kavramların net olarak tanımlanmadığı, kavramlarla nelerin kastedildiği anlaşılamadığı için sorunlar oluşmuştur. Din eğitimi kavramı pek çok raporda din öğretimi kavramı ile karıştııımış, seçmeli din dersleri ve DKAB dersleri arasındaki ayrım ortaya konulmamış, isteğe bağlı ve seçmeli din dersleri birbirlerinin yerine kullanılmış ve kavramlar net olarak tanımlanma- 
mıştır. Bu kavram karmaşası raporların değerlendirilmesinde de sıkıntılar doğurarak, kavramlarla neler kastedildiği, kavramların içeriklerine neler yüklendiği, araştırmacının raporları tek tek ele almasıyla belirlenmeye çalışılmıştır.

Ensar Vakfı ve Değerler Eğitimi Merkezi (DEM), okullarda okutulan seçmeli din derslerini, isteğe bağlı din dersleri şeklinde ele almış, Eğitim-Bir-Sen, din eğitimi ve din öğretimi kavram karmaşasına düşmüştür.

İLKE (İlim, Kültür, Eğitim Derneği), DKAB derslerinin Batı'daki, "çok değer odaklı" din eğitimi yaklaşımının, Türkiye'ye "mezhepler üstü" din eğitimi olarak transfer edildiğini ancak bu eğitimin din eğitimi ihtiyacını karşılamadığını belirtmesine rağmen bu eğitimin niçin din eğitimi ihtiyacını karşılamadığına yer vermemiştir. İLKE Derneği kendi algıladığı din eğitimi kavramını da tanımlamamış, isteğe bağlı ve seçmeli din dersleri kavramlarını birbiri yerine kullanarak kavram karmaşasına rapor boyunca devam ettiği gözlemlenmiştir.

TiMAV (Türkiye İmam Hatipliler Vakfı) din öğretimi konusuna odaklanmış, okullarda din derslerinin diğer derslerle ilişkilendirilerek sunulması gerektiğini belirtmiş, seçmeli din dersleri ile ilgili görüşlerini sunmuştur.

Türkiye'de son dönemlerde din eğitimindeki gelişim ve değişim sürecini değerlendiren Eğitim Reformu Girişimi (ERG) tarafından hazırlanan raporda, daha önce belirtilen hususlardaki kavram karmaşası dile getirilerek kullanılan kavramların net olarak ortaya konulamadığı ve bu durumun toplumsal uzlaşıyı etkilediği belirtilmiştir. İslami hassasiyeti olan STK'ların din eğitimi ile ilgili kavramları tam olarak ortaya koymayıp, kavramların tanımlarını yeteri kadar açıklayamadıkları göz önüne alındığında tartışmaların ortak bir noktada buluşması zor görünmektedir.

\section{Raporlarda Din Eğitimi Müfredatına Iliş̧kin Değerlendirmeler}

Ensar Vakfı tarafından hazırlanan raporda, din eğitimi ve dinler hakkında eğitim kavramları kullanılarak, iki farklı eğitimden bahsedilmektedir. DKAB dersi, dinler hakkında bilgi aktarımı amaçlı bir kültür dersi (yani dinler hakkında eğitim), din eğitimi dersi ise, dinî eğitim almak isteyenler için sunulan tercihe bağlı bir imkândır (seçmeli din dersleri). Burada DKAB dersi zorunlu olacak, "İslam Din Eğitimi", "Alevilik Din Eğitimi” dersleri ise isteğe bağlı ve seçmeli ders olarak okutulması sağlanacaktır. Aynı raporda, DKAB dersinin birinci sınıftan lise son sınıfa kadar zorunlu olarak okutulması gerektiği vurgulanmıştır.

Eğitim-Bir-Sen tarafından yayımlanan raporda, "4+4+4'ün toplumun çeşitliliğini ve farklı taleplerini dikkate alarak, seçmeli Kürtçe ve din eğitimi derslerini getirmesi, eğitim sisteminin en çok eleştirilen tek tip insan yetiştirme handikabını ortadan kaldırma potansiyeli taşımaktadır" ifadesi ile "Ak Parti'nin öncülüğünde, MHP ve BDP'nin dinî içerikli seçmeli derslerin kanunlaşmasına destek vermeleri, dinî öğretime yönelik toplumsal talebin olduğunu göstermiştir. Bundan dolayı bu derslerin seçmeli ders olarak tanımlanması genel olarak kamuoyunda olumlu karşılanmıştır" ifadeleri din eğitiminin daha çok siyasi boyutunu ele alıp değerlendirmelerinin bir sonucudur. Aynı raporda, seçmeli din derslerinin sayısının ve ders sürelerinin arttırılmasının önemli olduğu belirtilmiş, toplumsal uzlaşı ile bu durumun benimsendiği yorumları yapıımıştır (Eğitim-Bir-Sen, 2013, 56). 
İLKE Derneği'nin raporunda; veli ve öğretmenler, 4+4+4 eğitim reformu ile yürürlüğe giren seçmeli din derslerinin, uzun dönemden beri ihmal edilen ve eksikliği hissedilen din eğitimi alanında yeni bir vizyon sunacağını belirtmişlerdir. Yeni eğitim sistemi ile din eğitimi ihtiyacının karşılanmasına yönelik en ciddi adımların atıldığı belirtilmiştir. Ayrıca Kur'an'ı hayatlarında önemli gören katılımcılar, bunun Hz. Peygamber'in söz ve davranışlarıyla desteklenmesi gerektiği hususunu dile getirmişlerdir. Katılımcılar ancak Kur'an ve sünnet temelli eğitimle, çocuklarında İslami bir bilincin oluşacağını ifade etmişlerdir. Araştırma bulgularında öğrenciler, derslerde inanç ilkelerinin, ibadetlerin ve bazı ahlak konularının sürekli tekrar ettiğini ancak günlük hayatlarında karşılaştıkları problemli konular hakkında yeteri kadar bilgi verilmediğini belirtmişlerdir. Aynı araştırmada, öğretmenlerin din derslerinin öğretimi konusunda zorlandıkları görülmüş, pek çok öğretmenin dersi kaliteli ve verimli hâle getirmek için farklı yöntem ve teknikleri kullandıkları belirtilmiş ancak bazı öğretmenlerinde dersleri işleme konusunda zorlandığı hatta veremeyeceği düşüncesine sahip olduğu tespit edilmiştir.

TiMAV tarafından öneri mahiyetinde hazırlanan raporda, "Din Kültürü ve Ahlak Bilgisi dersinin zorunluluğu korunmalı; bunun dışındaki din eğitim ve öğretimi, din ve eğitim özgürlüğü bağlamında ele alınarak düzenlenmeli" ifadeleri yer almış, bu ifadeler 12 yıllık zorunlu eğitim sisteminde de yerini bulmuştur. Ensar Vakfı gibi TiMAV'da DKAB derslerinin birinci sınıftan itibaren başlatılması gerektiğini ortaya koymuştur. DKAB ders müfredatının mezhepler arası anlayışa uygun bir şekilde devam ettirilmesi dile getirilmiştir. Ayrıca DKAB derslerine ek olarak, diğer derslerde kendisiyle ilgili konuların dinî açıdan yorumlarını sunan bir din dersi beklenilmiş ve diğer derslerde de dine yer verilmesi gerektiği belirtilmiştir.

\section{Raporlarda Programların Yapısına (Kazanım, Etkinlikler, Ölçme Değerlendirme) İlişkin Değerlendirmeler}

Değerler Eğitim Merkezi'nin hazırladığı raporda, 4+4+4 eğitim sistemi ile müfredata konuIan Temel Dini Bilgiler (İslam I-II), Kur'an-ı Kerim ve Hz. Muhammed'in Hayatı derslerine ait öğretim programlarının içeriği ve kazanımlarının hem kendi içerisinde hem de birbiri arasında bütünlük taşıyacak şekilde modüler tarzda oluşturulması gerektiği ifade edilmiştir. Din derslerinde öğretim programlarının bir programda olması beklenen öğelere dair bilgileri yeterince içermediği, öğretmenin rolünün yeteri kadar açıklanmadığı, "açıklamalar" kısmında dersin uygulayıcılarına yardımcı olabilecek açıklamalara yeterince yer verilmediğine dikkat çekilmiştir. Öğrencilerin edinmesi hedeflenen bilgi, değer, beceri ve tutumların, bilişsel ve duyuşsal alana yönelik yazıldığı, psikomotor alana ait kazanımlara hemen hemen hiç yer verilmediği dile getirilmiştir.

DEM raporunda, seçmeli din dersleri programlarında ölçme-değerlendirmeye yönelik, hangi yöntem ve tekniklerin kullanabileceği, ne tür etkinlikler yapabileceği konusunda bilgiler bulunmadığı ve örneklere yeteri kadar yer verilmediği ifade edilmiştir. Ayrıca ilköğretim kurumları yönetmeliğinde yer alan "seçmeli derslerin notla değerlendirilemeyeceği" hükmü ile belirtilen seçmeli din derslerinin de ortaokullarda notla değerlendirilememesinin önemli bir eksiklik olduğu raporda yerini almıştır. 
DEM ayrıca ders kitaplarına da dikkat çekerek, konu ve alt başıkların yeteri kadar yazılmadığı belirtilmiştir. Ders kitapları hazırlanırken yazarların ya da yayınevlerinin sadece konu başıklarından ve kazanımlardan hareket ettikleri, konuların ayrıntılarına yer vermediklerine vurgu yapılmış, bu ayrıntıların gözden kaçııımaması gerektiği savunulmuştur. Ayrıca Kur'an-ı Kerim dersinin gereği olan tecvit kurallarının sadece lisede değil ortaokulda da verilmesi gerektiğinin altı çizilmiştir.

İLKE Derneği, din derslerinin içeriğinin dinî bilgiler olduğunu, dinî bilginin kaynaklarının ise Kur'an ve sünnet olduğunu belirterek, derslerin konu alanı, birey ve toplumun ihtiyaçlarını karşılayacak şekilde, İslam dininin temel kaynaklarından yararlanarak oluşturulması gerektiği hususunun altını çizmiştir. Raporda, Kur'an-ı Kerim derslerinde yer alan alt konuların, ortaokul ve imam hatip ortaokul düzeyindeki öğrenciler için uygun iken, ilk defa bu dersi lisede alacak öğrenciler için zorluk derecelerinin yüksek olduğu belirtilmiştir. Tecvit dersinin uygulamalı olarak yaptırılması gerektiği ve psikomotor becerilerin geliştirilmesi açısından önem arz ettiği bir başka konu olarak ele alınmıştır.

İLKE Derneği, "Hz. Muhammed'in Hayatı" dersinin tematik yaklaşıma göre hazırlanmasını yapısal açıdan köklü bir değişim olarak görmüş, bu dersin DKAB dersindeki " $\mathrm{Hz}$. Muhammed" öğrenme alanıyla ilişkilendirildiğini ancak bu ilişkilendirmede teknik hatalar bulunduğunu bununla beraber bu yaklaşımın olumlu olduğu görüşü dile getirilmiştir. Kaymakcan'ın (2013) ifade ettiği, Hz. Muhammed'in Hayatı dersinde farklı sınıf düzeylerinde yer alan temaların/ünitelerin birbirinin tekrarı şeklinde yazıldığı intibaının oluştuğunu ancak bu yorumun çok doğru olmadığını, kazanım ve içerik boyutlarının birbirinden farklı olduğunu belirtmiştir. Ayrıca İLKE Derneği, Temel Dinî Bilgiler dersinin, ilk ve ortaöğretim DKAB programlarıyla örtüştüğünün gözüktüğünü ifade etmiştir.

TiMAV'ın ders içerikleri ile ilgili ortaya koyduğu ifadeler, din derslerinin disiplinler arası yaklaşımla ele alınması açısından önemlidir. “Disiplinlerin kendi içlerinde dinden bağımsız ve habersiz gibi davranması mümkün olmadığı gibi din öğretiminin de kendi süreçlerinde diğer disiplinlerden yardım almaması düşünülemez. Herhangi bir ders içinde bir konu üzerinde dinsel etkiden bahsetmek mümkünse veya bazı konularda seküler ve dinsel bakış açılarının karşılaştırılması gerekiyorsa dinin de bakış açılarının öğretime girmesi gerekir" ifadelerini kullanarak disiplinler arası eğitimin olması gerektiği vurgulanmıştır.

\section{STK'ların İsteğe Bağlı ve Seçmeli Din Derslerinden Beklentilerine İlişkin Değerlendirmeler}

Ensar Vakfı hazırladığı raporda, isteğe bağı din eğitiminin MEB tarafından okullarda uygulanması, pedagojik formasyon sahibi fakülte mezunlarınca verilmesi ve ücretsiz olması gerektiğini ifade etmiştir. Bu uygulamanın sağlıksız ve kontrolsüz ortamlara bırakılan din eğitiminden daha fazla tercihe yakın olduğunu dile getirmiştir.

DEM tarafından hazırlanan raporda, seçmeli din derslerinin, siyasi değişimlerden etkilenmeyecek şekilde, gerçekçi, kuşatıcı ve güvenilir bir din eğitimine katkı sağlayacağı belirtilmiştir. DEM, seçmeli din dersleri ve isteğe bağlı din derslerinin ne zaman, nerede ve kimler tarafından verileceğini Ensar Vakfı'nın hazırladığı rapora atıfta bulunarak açıklamıştır. 
Eğitim-Bir-Sen tarafından hazırlanan raporda, seçmeli din derslerinin okullardaki uygulamasına yer verilmiş, okullarda bu derslerin seçilmesi, okulun fizik şartlarında yaşanan sıkıntılar, okul yöneticileri, veli ve öğrenci bakış açılarıyla sorgulanmıştır. Burada isteğe bağı din eğitimine yer verilmemiştir.

İLKE Derneği tarafından yayımlanan raporda isteğe bağlı seçmeli din derslerinden bahsedilerek, toplumun din eğitimi konusundaki ihtiyaçlarının karşılanmasına yönelik en ciddi ve reel uygulama olduğuna dikkat çekilmiştir. İsteğe bağlı seçmeli din dersleri kavramından hareket ederek bir tanımlamaya varan ILLE Derneği, bu derslerin müfredata eklenmesiyle, derslere yönelik eleştirilerin azalabileceği ve meşruluğunun artabileceğini araştırma sonucunda ortaya koymuştur.

TiMAV tarafından hazırlanan raporda, seçmeli din derslerinin okullarda ve seçmeli olarak, modüler hâlde okutulması kararı foruma katılanlarca ortaklaşa alınmışır.

\section{İsteğe Bağlı Din Eğitimi Tartışmaları: Din Eğitimi-Öğretimi Okulda Mı, Okul Dışında Mı Yapılmalı?}

Araştırma raporlarında ulaşılan en önemli sonuçlardan birisi, isteğe bağlı din eğitimi hakkında yapılan-yapılmayan, değerlendirilen-değerlendirilmeyen konulardır. Bu çelişkili ifadelerin kullanılması önem ifade eder. Karmaşık ifadelerin araştırma raporlarında kullanılması bu raporları hazırlayan STK'ların din eğitimi ile ilgili düşüncelerinin net olmadığını da göstermektedir. İsteğe bağlı din eğitimi kavramının seçmeli din dersleri ile karıştırıldığı raporlarda isteğe bağlı din eğitimi talepleri bulunmamaktadır. İsteğe bağlı din eğitimi, genellikle okul dışı saatlerde, okul dersleri haricinde, okulun dışında farklı yerlerde (kilise, cami, kültür-inanç merkezleri vb.) verilen, çocuğun veya ailesinin okula özel talepte bulunarak, çocuğun ayrıca çaba sarf ederek aldığı derslerdir (ERG, 2012). Bu ifadeler ışığında STK'ların okul dışında eğitim talepleri, okul dersleri haricinde din dersi (ya da konuları) istekleri olmadığı için, isteğe bağlı din eğitimi talepleri bulunmamaktadır. Raporlarda isteğe bağlı din eğitimi, seçmeli din dersi olarak karıştırılmış, talepler, beklentiler, değerlendirmeler ve öneriler bu bağlamda yapılmıştır.

\section{Seçmeli Din Eğitimine İlişkin Öğrenci, Öğretmen ve Veli Tutumları}

Eğitim-Bir-Sen tarafından hazırlanan raporda yönetici, öğretmen, öğrenci ve veli tutumları hakkında bilgilere yer verilmiş ve bu kesimlerin çoğu seçmeli din dersi uygulamasını olumlu karşıladıklarını belirtmişlerdir. Seçmeli derslerden olan Kur'an-ı Kerim, Hz. Muhammed'in Hayatı ve Temel Dinî Bilgiler derslerinin konulması veliler tarafından olumlu karşılanmış ve bu derslerin seçilmesinde velilerin çocuklarını yönlendirdikleri sonucuna ulaşılmıştır. Katılımcılar, seçmeli derslerde en önemli sorunun öğretmen açığı olduğunu bu açığı kapatmak için üzere ücretli öğretmenlere okullarda yer verildiğini belirtmişlerdir. Bazı katılımcıların seçmeli derslerde not verilmemesinin derslerin ciddiye alınmadığını ifade ettiklerini, bazı katılımcıların ise, seçmeli derslere not verilmesinin uygun olmadığı ve bu derslerin mantığına aykırı olduğu yönünde görüş belirtmişlerdir. Katılımcılardan bazıları yaptıkları değerlendirmelerde okul yönetimi tarafından yönlendirildiklerini ve seçmeli ders olarak 
onların belirledikleri dersler dışında seçim yaptıklarında sorun yaşanabileceğini aktarmışlardır. Öğretmenler ise, genel olarak MEB tarafından kendilerine ders programı, ders kitabı, araç-gereç verilmediğini ve derslerin boş geçtiğini ifade etmişlerdir.

İLKE Derneği tarafından hazırlanan raporda öğrencilerin, veli ve öğretmenlerin gözünden din eğitimi ile ilgili görüşler yansıtılmıştır.

\section{Öğrencilerin Seçmeli Din Dersi ille ilgili Görüşleri}

Öğrencilerden bazıları seçmeli din derslerini okul idaresinin çeşitli yönlendirmelerle yaptıklarını belirtmelerine karşın, büyük bir kısmı, din dersine olan ilgi ve meraklarının belirleyici olduğunu dile getirmişlerdir. Dinî konularda kendilerini yetersiz gören ve bu yönlerini geliştirmek isteyen öğrencilerin de bu dersleri almalarında etkili olduğu sonucuna ulaşımıştır. Öğrencilerin din derslerini almalarına çevrelerinin de olumlu tepkiler verdiği raporda ayrıntılarıyla ele alınmıştır. Öğrenciler seçmeli derslerin okullarda yeteri kadar tanıtılmadığını ve kafalarının karışık olduğunu belirtmişlerdir. Öğrencilerin seçmeli din derslerinden en çok Hz. Muhammed'in Hayatı dersini sevdiklerini ve bu derse sık sık vurgu yaptıklarına aynı araştırmanın sonucunda ulaşılmıştır. Bu araştırma ile öğrenciler, namaz konularının ve Kur'an derslerinin önemine dikkat çekmiş ve öğrencilerin bu derslere karşı olumlu tutum sergiledikleri belirlenmiştir. Öğrencilerin dile getirdiği önemli etkenlerden biri de öğretmenlerin tutumudur. Öğrencilerin, öğretmenlerin tutumlarına bakarak derslere karşı olan tutumlarının da değiştiği gözlenmiştir.

\section{Velilerin Seçmeli Din Dersi İle İlgili Görüşleri}

Veliler, seçmeli din derslerinin okullarda öğretiliyor olmasını önemsemekte, bu ve benzeri derslerin ve uygulamaların sürdürülmesini istemektedirler. Ancak bu eğitimlerin kaliteli, işlevsel, çocukların duygu dünyasına girecek, davranış değişikliği oluşturacak, sorumluluk bilinci kazandıracak, hem İslam dinini öğretecek şekilde yapılmasını istemekte, hem de öğrencilerin hayatlarına dokunacak şekilde hazırlanması gerektiğini ifade etmektedirler.

Velilere göre, bu derslerden istenen başarılı sonuçlara ulaşabilmek için daha erken yaşlardan itibaren bu hususlara eğilmek gerekmektedir. Veliler aynı zamanda, din eğitiminin daha profesyonelce, daha kurumsal olarak ve bu alanda eğitim almış uzman kişiler tarafından okulda verilmesi gerektiğine vurgu yapmaktadırlar. Velilerin seçmeli din derslerini tercih etme nedenlerinden biri de, bu derslerin çocukların ruh sağlığına, değerler dünyasına ve manevi gelişimlerine olumlu katkılar sağlayacağını düşünmeleridir. Bir diğer neden ise, çocuklarının günlük hayatta karşılaştıkları dinî problemlere çözüm yeri olarak okulları görmek istemeleridir.

Velilerin seçmeli din dersleri ile ilgili şikâyetlerine de yer verilen raporda, istenilen derslerin seçilememesi ve okullarda din eğitiminin çocukların manevi ve dinî gelişimleri için yetersiz kalması hususları göze çarpmaktadır. Raporda ayrıca veliler, derslerin süresinin yeterli olmadığı, bu derslerin saatlerinin arttırıması ve derslerin okul saatlerinin sonuna bırakılmaması gerektiği hususlarının altını çizmişlerdir.

Seçmeli din derslerini okumalarını istemeyen öğrenci velilerin de görüşlerine yer verilen raporda ise ilginç sonuçlara ulaşılmıştır. Öğrencilerine seçmeli din derslerini okutmak istemeyen velilerin, bu tercihi yapmasındaki en önemli faktör, okullarda DKAB dersinin okutu- 
luyor olmasıdır. Bir diğeri neden ise, velilerin bu eğitimleri kendilerinin de verebileceğini düşünmelerdir. İdeolojik kaygılardan dolayı seçmeli din derslerini öğrencilerine aldırmayan veliler, dindar olmadıklarını, bu tür çevrelerinin de olmadığını belirterek, bu dersleri seçme gereği hissetmediklerini ifade etmişlerdir. Bu düşünceye sahip bir veli, DKAB dersinin zorunlu olmaması, seçmeli olması gerektiğini belirterek ön yargıya kapıldığını ifade etmiştir. DKAB dersinin zorunluluğu kaldırılırsa, seçmeli din derslerinin daha çok merak uyandırabileceği ve daha çok seçilebileceği belirtilmiştir. Seçmeli din derslerinin seçilmemesinde payı olan etkenlerden bir diğeri de, babaların dinî konulardaki duyarsızlığı ve din eğitimini çocukları için gerekli görmemeleridir. Ayrıca bunlara ek olarak veliler okulda bu dersleri verecek olan öğretmenleri alanlarında yetersiz olarak görmektedirler.

Velilerin seçmeli dersler konusunda okul yönetimi ile ilgili belirttiği kısımlar Eğitim-BirSen raporunda olduğu gibi burada da karşılık bulmaktadır. İLKE Derneği, okul idarelerinin tutumlarının birbirinden farklııık arz ettiğini, bazı okul yöneticilerinin seçmeli dersler hakkında açıklayıcı bilgi verdiğini ve yönlendirme yaptığını belirtirken bazılarının ise hiçbir yönlendirme yapmadıkları sonucuna ulaşmıştır. Ayrıca raporda, yöneticilerin bu yönlendirmeleri, okulun fizikî şartlarına ve öğretmen durumlarına bakarak yaptıkları, eğer okul seçmeli din derslerine uygun fizikî altyapı ve öğretmen kaynağı olarak yeterli değilse çocukları başka derslere yönlendirdiklerini belirtmişlerdir. Yine rapor sonucunda yöneticilerin bu yönlendirmelerin olumsuz bir durum olarak görülmemesini istemelerine de ulaşılmıştır. Yöneticilerin yaptıkları yönlendirmelerin yeterli olduğunu söylemek mümkün olmamakla beraber bu eksikliğin bazı derslerin alınmaması ile sonuçlandığı görülmüştür.

Seçmeli din derslerinin hem okulda hem de dışında verilebileceğini düşünenler olduğu gibi abdest alma vb. sebeplerden ötürü cami ortamının bu derslerin eğitimi konusunda daha etkili ve verimli olacağına dikkat çeken velilerde bulunmaktadır.

\section{Öğretmenlerin Seçmeli Din Dersi İle IIIgili Görüşleri}

Öğretmenler, okullarda zorunlu olarak okutulan DKAB dersinin ve yaz Kur'an kurslarının çocukların manevi gelişimlerine yeterli katkı sağlamadığını, yeni seçmeli din derslerinin bu durumu ortadan kaldırabileceğine olan inançlarını dile getirmişlerdir. Seçmeli din derslerinin isteğe bağlı olarak okutulmasını demokratik bir adım olarak niteleyen öğretmenler, bu sayede bu derslerin de meşruluk kazandığını ve eleştirilerin önünün tıkandığını düşünmektedirler. Öğretmenlere göre bu dersler, öğrencilerin günlük hayatlarında karşılaştıkları birtakım problemlere çözümler önermekte; iyi ve doğru davranışlar geliştirmelerine yardımcı olmakta ve böylelikle zaman içinde dindar ve ahlaklı bir neslin yetişmesine öncülük etmektedir.

Öğretmenlerin bir kısmı derslerin gerekli fizikî şartlar oluşturulmadan, hızlı bir şekilde öğretim programlarına dâhil edildiğini belirterek bu durumun kendileri de dâhil olmak üzere pek çok kişiyi mağdur ettiğini belirtmişlerdir. Öğretmenler tarafından dile getirilen bir başka husus ise bu derslerin süresinin az olması ve günün son derslerine bırakılmasıdır. Çocukların son derslerde yorgun olduklarını ve sıkıldıklarını ifade eden öğretmenler, bu saatlerde öğrencilerin derse olan ilgisinin azaldığını savunmuşlardır. 


\section{Raporlarda Yeni Eğitim Sistemine İlişkin Öneriler}

Ensar Vakfı öneriler başlığı altında şu hususların altını çizmektedir. Öğrencilere isteğe bağlı din eğitiminin daha etkili olması ve denetiminin daha iyi sağlanabilmesi için okullarda verilmesinin daha uygun olacağı belirtilmiş, üniversite mezunu pedagojik formasyon almış öğreticiler tarafından ve ücretsiz olarak verilmesi gerektiği önerilmiştir. "İsteğe Bağlı Din Eğitimi Çalıştayları" MEB tarafından isteğe bağlı din eğitimi politikalarını belirlemek, uygulama esaslarını çizmek, öğretim programları ile fizikî koşulların ve ders materyallerinin nasıl hazırlanacağı vb. konuları görüşmek ve istişare etmek üzere en geniş katılımla acilen toplanması gerektiği önerilmiştir. Ensar Vakfı tarafından hazırlanan raporda, "DKAB dersinin ilkokul birinci sınıftan lise son sınıfa kadar içeriği yeniden düzenlenmek suretiyle zorunlu olarak okutulması sağlanmalı" ifadesi dikkat çekicidir.

DEM'in raporunda genel sonuçlar ve öneriler başlı̆̆ı altında dikkat çekici unsurlar görünmektedir. Zorunlu veya seçmeli din derslerinin öğretim programlarının temelinde yer alan yaklaşımlarla ilgili bilgilerin yer almadığı ve bu durumun sıkıntılar doğurduğu belirtilmektedir. Raporda din derslerinin, içeriğinin, öğretme-öğrenme süreçlerinin ve ölçmedeğerlendirme araçlarının, öğretmen rollerinin, açıklama kısımlarının, başlıklar-alt başlıklar arasındaki uyumsuzluğun altı çizilerek yeniden yapılandırılması gerektiği dillendirilmiştir. DEM'e göre, öğretim programları, bu derslere özgü bilişsel, duyuşsal ve psikomotor becerileri ölçecek şekilde yeniden ele alınmalı ve bu derslerin yönetmeliğinin tekrar düzenlenerek notla değerlendirilmesinin önü açılmalıdır.

Eğitim-Bir-Sen öneriler kısmında, seçmeli derslerin hedefine ulaşabilmesi için, bu dersleri seçen öğrencilerin ve bu dersi veren öğretmenlerin daha dikkatli seçilmesi gerektiği bununla beraber okulların seçmeli derslere uyum sağlayabilmesi için fizikî mekânların ve öğretim materyali ihtiyacının karşılanması için gerekli hazırlıkların bir an önce bitirilmesi gerektiğinin altı çizilmiştir.

ÍLKE Derneği öneriler başığı altında, seçmeli din derslerinin öğretim programında dikkate alınması gereken hususlar, seçmeli din derslerinin kalitesinin arttırılması konusunda MEB'e, YÖK'e, öğretmenlere düşen görevler ve seçmeli derslerin seçimini arttırmaya yönelik yapılması gerekenleri ayrı başlıklar halinde toplayıp, önerilerini paylaşmıştır. Seçmeli din derslerinin öğretim programlarında dikkate alınması gereken hususların başında hedef, içerik, öğrenme-öğretme durumları ve değerlendirme boyutlarıyla ilgili çalışmalara ağırlık verilmesi, kazanımların daha çok bilişsel alanla sınırı kaldığı, duyuşsal ve psikomotor alana ağırlık verilmesi gerektiği, içerik oluşturmada İslam dininin temel kaynaklarının merkeze alınması gerektiği, seçmeli derslerle ilgili olarak sınavların olması gerektiği önerilmiştir.

İLKE Derneği raporunda, seçmeli derslerin kalitesinin arttırılması noktasında, öğretmen sayısının arttırılması, idarecilerin derslere girmemesi, okulların fizikî yapısının uygun hâle getirilmesi, ders kitaplarının ilgi çekici hâle getirilmesi, çocukların abdest alabilecekleri ortamların oluşturulması için MEB'in harekete geçmesi önerilmiştir. YÖK'ten beklentilere bakıldığı zaman, Illahiyat fakültesi ve ilköğretim DKAB öğretmenliği bölümü okuyan öğrencilerin İslami bir bilinçle yetiştirilmesi ve ruh kazandırma amaçlı çalışmalar yapılması gerektiği önerilmiştir. Bu noktada öğretmenlere büyük görev düştüğünü belirten raporda, derslerde kullanılacak olan araç-gereç ve materyallerin daha nitelikli olması ve öğrencilerde 
ilgi, tutum ve davranış değişimini sağlayacak şekilde kullanılması gerektiği belirtilmiştir. Derslerin içerikleri ile detaylı bilgilere yer verilen raporda, Kur'an derslerinin öğretimine yönelik hassas davranılması gerektiği, Kur'an okuma bilinci kazandırılması gerektiği, ayetlerin anlamlarına yönelik meal okuması yapılması gerektiği belirtilmiştir. Hz. Peygamber'in öncülüğünde yetişen sahabelerin hayatından derslerde örnekler verilmesi gerektiği, günlük hayattaki uygulamaların $\mathrm{Hz}$. Muhammed'in örnekliğinde açıklanması gerektiği, gereğinden fazla kronolojik bilgi vermekten kaçınılması gerektiği önerilmiştir.

İLKE Derneği, velilerin seçmeli derslerle ilgili bilgilendirme düzeyinin arttırılmasını, seçmeli din derslerinin öğretmenlerin yönlendirilmesine bırakılmamasını, Hz. Peygamber'i temel alan çeşitli etkinlikler düzenlenerek, çocukların bu etkinliklerde yer almasının sağlanması gerektiğinin altını çizmiştir.

TiMAV yayımladığı raporda (bu rapor 4+4+4 eğitim sistemi zorunlu olmadan kısa bir süre önce yayımlanmıştır), DKAB dersinin 1. sınıftan itibaren zorunlu olması ve derslerin mezhepler arası anlayışa uygun bir şekilde devam ettirilmesi belirtilmiştir. Öğretim programında bağımsız bir ders olmakla birlikte diğer derslerde de din dersinden yararlanan bir din öğretiminin benimsenmesi gerektiği ifade edilmiştir. TiMAV, din derslerinde değerler eğitiminin de verilmesi gerektiğini, ders kitaplarının uzmanlarca hazırlanması gerektiğini, özel eğitime gereksinim duyan çocuklara uygun programların hazırlanması gerektiğine vurgu yapmıştır. Öğretmen yeterliliklerine yeteri kadar önem verilmediği, DKAB bölümlerinin eğitim fakültelerinden alınıp, İlahiyat fakültelerine verilmesi gerektiği, İmam Hatip liselerinin meslek lisesi kapsamından çıkarılması gerektiğinin altı çizilmiş̧tir.

\section{Sonsöz ve Öneriler}

Seçmeli din dersleri konusunda rapor hazırlayan STK'ların, rapor hazırlarken din eğitimi ile ilgili kavramları açıklayarak çalışma yürütmeleri gereklidir. Hazırlanan raporlarda toplumun, okuyucunun ve bilimsel çalışma yapan akademisyenlerin aynı düşünleri ve fikirleri anlaması önem arz eder. Raporlarda yer yer bu hususlar gözden kaçmış ve yanlış anlaşılmalara mahal verebilecek durumlar ortaya çıkmıştır. Bundan dolayı, raporlarda kullanılan kavramların tanımlanması ve bu tanımların üzerine düşüncelerin bina edilmesi gerekir.

Seçmeli din dersleri konusunda STK'lar, ders içeriklerini değerlendirmiş, ders içeriklerinin zenginleştirilmesini, hedeflerin (kazanımların) tutarlı olmasını, konuların-alt konularla ilişkili olmasını, kullanılan araç-gereçlerin yeterince sağlanmasını ve değerlendirmelerin sınavlar yapılarak olması gerektiği genel bir kanı olarak ortaya çıkmıştır. Araştırma raporlarında bir diğer ortak nokta, din derslerinin günlük hayatla daha ilişkili kılınması, güncel sorun ve problemlere karşılık vermesi ve diğer derslerle ilişkili olması gerektiği ifade edilmiştir.

Araştırmada ulaşılan en ilginç sonuçlardan birisi de, STK'ların okul dışında eğitim talepleri ile okul dersleri haricinde din dersi (ya da konuları) isteklerinin ve isteğe bağlı din eğitimi taleplerinin bulunmamasıdır. Bununla beraber raporlarda, isteğe bağlı din eğitimi, seçmeli din dersleri ile karıştırılmış, talepler, beklentiler, değerlendirmeler ve öneriler bu bağlamda yapılmıştır. 
Din eğitimi konusunda çalışma yapan ve rapor sunan sivil toplum kuruluşlarının talepleri, beklentileri, önerileri ve değerlendirmeleri, okullarda din öğretiminin geliştirilmesi konusunda etkili olmuştur. Devlet politikalarında bu raporların etkisi her geçen gün daha da belirgin şekilde görülmektedir. Okullarda seçmeli dersler, ders saatleri ve değerler eğitimi ile ilgili düzenlemeler bunun en açık göstergeleri olmuştur. Ancak bu düzenlemelerin etkisini ölçmek ve süreci izlemek de en az bu düzenlemeleri yapmak kadar önemlidir. Bu noktada STK'ların kapsamlı, eleştirel ve bilimsel bir bakış açısıyla süreci değerlendiren raporlarına ihtiyaç vardır. Hazırlanacak bu çalışmalar, STK'ların kendi talepleri noktasındaki düşüncelerini daha somut olarak değerlendirme imkânı sunacaktır.

Din eğitimi ile ilgili farklı inanç kesimlerinin taleplerini de ortaya koyan çalışmalara ihtiyaç vardır. Genel olarak raporlar, İslam dini üzerinde durup çalışmalarını şekillendirmişler, farkıı inanç kesimlerine yeteri kadar yer vermemişlerdir. Raporların hazırlanma amaçları farkı inanç kesimlerinin isteklerini sunmak olmasa bile toplumsal uzlaşıyı sağlayacak ortamların oluşması raporlarda dahi önemlidir. Toplumun bir kesiminin din eğitimi ihtiyacını kamusal alana yaymak ile ilgili görüşleri raporlarda yeterli ilgiyi görmemiştir. Avrupa'da din eğitiminin kilise ve devlet arasında paylaştırılma uygulamaları Türkiye'de hazırlanan raporlarda yerini bile almamıştır. STK'ların en önemli taleplerinin isteğe bağlı din eğitimi olması gerektiği çalışmanın birçok yerinde ifade edilmiştir. Bunun için STK'lar, isteğe bağlı din eğitimi konusunda cami-cemevi-dergâh-STK-okul ilişkisini yakalayabilecek farklı söylemler üretebilmelidirler.

STK'lar seçmeli din derslerinin sorunları olarak, okulların bu derslere yönelik hazırlıklı olmamasını, öğretmen yeterliliklerini ve öğretmen açığı gibi hususları belirtmişlerdir. Bu sorunların çözümüne yönelik MEB'den, YÖK'ten, STK'lardan beklentiler sıralanarak, din eğitimi ve din öğretimi konularında ortaklaşa düzenlenebilecek forumlarda etraflıca tartışılması gerektiği belirtilmiştir.

Araştırma raporlarının din öğretimi ile ilgili taleplerini kamuoyu ve paydaşlara açıklaması, beklentilerini, taleplerini, önerilerini dile getirmiş olması, demokrasinin bir gereği olarak önem ifade etmektedir. Araştırma raporlarının, dünyanın farklı coğrafyalarında din eğitimi ve öğretimi konusunda örneklerin sunulduğu ve toplumsal koşulların dikkate alınarak hazırlanan araştırma raporlarına intiyaç duyulmaktadır.

\section{Kaynakça}

Armaner, N. (1958). Okullarımızda din öğretimi üzerine. Ankara Üniversitesi llahiyat Fakültesi Dergisi, 7(1), 115-117.

Aydın, M. Z. (2007). Okulda din dersi tartışmaları (Türkiye'de din dersinin tarihi, teorik yapısı, bazı ülkelerle karşılaştırılması). Cumhuriyet Üniversitesi Ilahiyat Fakültesi Dergisi, XI(2), 7-51.

Ayhan, H. (2004). Türkiye'de din eğitimi. İstanbul: Dem.

Bahçekapılı, M. (2013). Yeni eğitim sisteminde seçmeli din dersleri, imkânlar, fırsatlar, aktörler, sorunlar ve çözüm önerileri. İstanbul: Illke. www.ilke.org.tr/wp-content/uploads/2013/12/4+4+4-Araştırma-Raporu. pdf adresinden 19 Kasım 2014 tarihinde edinilmiştir.

Boz, N., Çelik, Z., Gümüş, S., Orçan, M., Taştan F. (2013). 4+4+4 eğitim reformunu izleme raporu. İstanbul: Eğitimciler Birliği Sendikası. www.egitimbirsen.org.tr/ebs_files/files/.../267-egitimbirsen.org.tr-267.pdf adresinden 19 Kasım 2014 tarihinde edinilmiştir. 
Çekin, A. (2013a). Bilim-din ilişkisinin Hristiyan din eğitimine yansımaları ve bilimsel din eğitimi yaklaşımı. International Journal of Social Science, 6(3), 135-148.

Çekin, A. (2013b). Din eğitimi. İnsan ve Toplum Bilimleri Araştırmaları Dergisi, 2(3), 136-150.

Çelikkaya, H. (1996). Din eğitiminin özellikleri ve genel kuralları. Fidan Dergisi, 19, 5-7.

Ensar Vakfı. (2012). 4+4+4 eğitim sistemi, yeni anayasada dinî kurumlar, din eğitimi ve öğretimi, isteğe bağlı din eğitimi. İstanbul. https://www.ensar.org/img/20130731_7860834002.pdf adresinden 19 Kasım 2014 tarihinde edinilmiştir.

Erdoğan, İ. (2014). 2023'e doğru Türkiye'nin eğitim tasavvuru. Yeni Türkiye Dergisi, 56, 598-606.

Ergüder, Ü. (2011). Türkiye'de din ve eğitim son dönemdeki gelişmeler ve değişim süreci. İstanbul: Eğitim Reformu Girişimi. http://erg.sabanciuniv.edu/sites/erg.sabanciuniv.edu/files/DinVeEgitim.pdf adresinden 19 Kasım 2014 tarihinde edinilmiştir.

Fuess, A. (2007). Islamic religious education in Western Europe: Models of integration and the German approach. Journal of Muslim Minority Affairs, 27(2), 215-239.

Halstead, J. M. (2005). Encyclopedia of Religion. Lindsay Jones (Ed.), Religious education içinde (2. Baskı s. 7731-7736), Detroit: Macmillan.

Hunkins, P. C. ve Ornstein C. A. (2014). Eğitim programı, temeller, ilkeler ve sorunlar. Konya: Eğitim.

Kap, D. (2014, Kasım). Türkiye'de zorunlu din dersi uygulaması. Akademik Perspektif, 58-61.

Kaymakcan, R. (2005). Türkiye'de misyonerlik ve din eğitimi. Sakarya Üniversitesi Illahiyat Fakültesi Dergisi, 12, 25-39.

Kaymakcan, R., Aşlamacı, İ., Yılmaz, M., Telli, A., vd. (2013). Seçmeli din eğitimi dersleri inceleme ve değerlendirme raporu. İstanbul: Dem. https://www.ensar.org/img/20130731_1318170429.pdf adresinden 19 Kasım 2014 tarihinde edinilmiştir.

Koçer, A. H. (1967). Türkiye'de öğretmen yetiştirme problemi. Ankara: Yargıçoğlu Matbaası.

Milli Eğitim Bakanlığı (MEB). (2012). 12 yıllık zorunlu eğitim, sorular-cevaplar. Ankara. www.meb.gov.tr/ duyurular/duyurular2012/12Yil_Soru_Cevaplar.pdf adresinden 19 Kasım 2014 tarihinde edinilmiştir.

Norveç Helsinki Komitesi: İnanç Özgürlüğü Girişimi. (2014). Türkiye'de inanç özgürlüğü hakkını izleme raporu. İstanbul. http://inancozgurlugugirisimi.org/calismalarimiz/turkiyede-inanc-ozgurlugu-hakkiniizleme-raporu-yayinlandi-temmuz-2013-haziran-2014/adresinden 19 Kasım 2014 tarihinde edinilmiştir.

Okumuşlar, M. (2012). Türkiye'de din öğretimi forumu sonuç raporu. Konya: Türkiye İmam Hatipliler Vakfı. www.timav.org.tr/dosya/dinogretimiformu.pdf adresinden 19 Kasım 2014 edinilmiştir.

Okutan, Ö. (1980). Cumhuriyet döneminde din eğitimi ve öğretimi öğretmeni yetiştirme sorunu. (Yayımlanmamış yüksek lisans tezi). Ankara Üniversitesi Eğitim Fakültesi, Ankara. 